\title{
Rapid Cold Hardening Confers a Transient Increase in Low Temperature Survival in Diapausing Chilo suppressalis Larvae
}

\author{
Guangping Yang ${ }^{1}$, Jihui Wen ${ }^{2}$, Yongqiang Han ${ }^{2}$ and Maolin Hou 1,3,4,* \\ 1 State Key Laboratory for Biology of Plant Diseases and Insect Pests, Institute of Plant Protection, \\ Chinese Academy of Agricultural Sciences, Beijing 100193, China; 2009newlife@sina.com \\ 2 Institute of Plant Protection, Hunan Academy of Agricultural Sciences, Changsha 410128, China; \\ jihuiwen2005@126.com (J.W.); hanyongqiang1984@163.com (Y.H.) \\ 3 Southern Regional Collaborative Innovation Center for Grain and Oil Crops in China, \\ Changsha 410124, China \\ 4 Scientific Observing and Experimental Station of Crop Pests in Guilin, Ministry of Agriculture, \\ Guilin 541399, China \\ * Correspondence: mlhou@ippcaas.cn; Tel.: +86-10-6281-8641
}

Received: 31 March 2018; Accepted: 7 May 2018; Published: 9 May 2018

\begin{abstract}
The striped stem borer, Chilo suppressalis (Walker), overwinters as a diapausing larva. The diapausing larvae were tested for a rapid cold hardening ( $\mathrm{RCH})$ response and its role in the insect's survival of sub-zero temperatures. When laboratory-reared diapausing larvae were transferred directly from the rearing temperature of $25^{\circ} \mathrm{C}$ to $-14{ }^{\circ} \mathrm{C}$ and maintained there for $2 \mathrm{~h}$, $21 \%$ survived. Acclimation of diapausing larvae for $4 \mathrm{~h}$ at $5{ }^{\circ} \mathrm{C}$ before their exposure for $2 \mathrm{~h}$ to $-14{ }^{\circ} \mathrm{C}$ increased survival to approximately $41 \%$, indicating an $\mathrm{RCH}$ response. Durability of $\mathrm{RCH}$ effects on low temperature survival was less than $1 \mathrm{~h}$. Although transient in the test, the increased survival acquired through rapid cold hardening may play a role in preparing the diapausing larvae for abrupt temperature drops in the field that would otherwise be lethal.
\end{abstract}

Keywords: striped stem borer; rapid cold hardening; cold tolerance; overwintering; diapause

\section{Introduction}

Cold tolerance is important in defining an insect's distribution and survival [1]. Cold tolerance can be achieved through long-term cold acclimatization, where the overwintering insects experience natural and gradual temperature changes; and through rapid cold hardening $(\mathrm{RCH})$, where the overwintering insects experience a natural sudden temperature decrease for a short duration [2]. In natural environments, overwintering insects may be exposed to sudden decreases in temperature in spring and autumn when seasonal adaptations are either incomplete or receding [3,4]. In laboratory tests, when pre-treated by a non-lethal low temperature, insects are able to survive a subsequent cold event that would otherwise be lethal, which is an indication of $\mathrm{RCH}$ [4]. While seasonal acclimatization may take a long time to increase low temperature survival, $\mathrm{RCH}$ can enhance cold tolerance in such a short time as $30 \mathrm{~min}[5,6]$. RCH has been documented across numerous insect taxa to enhance survival to acute cold stress [4-14], however the cold tolerance gained through RCH is transient [3,8-10].

The striped stem borer, Chilo suppressalis (Walker) (Lepidoptera: Crambidae), is an insect pest of rice and is distributed in all the rice planting areas in China (from $18^{\circ} \mathrm{N}$ to $46^{\circ} \mathrm{N}$ ) [15]. The insect enters diapause in autumn principally in response to a short day length [16] and overwinters as diapausing larvae in rice stubble near the soil [17]. The overwintering C. suppressalis larvae avoid freezing by supercooling, both progressively decreasing temperatures and diapause contribute to 
supercooling capacity in the overwintering larvae [18]. Decreasing soil moisture also adds to their cold tolerance, with supercooling capacity at the highest when the saturated soil water content is $25 \%$ [19]. The supercooling capacity is the lowest in the winter and lower in the over-wintering population in water-oat than in rice [15]. Both diapause and cold-acclimation are essential for the avoidance of freezing injury due to their roles in accumulating glycerol and activating aquaporin [18]. Studies on cold tolerance in diapausing C. suppressalis larvae have focused on seasonal acclimatization. However, the overwintering insects may also experience sudden temperature decreases in the autumn and early winter. Qiang, C.-K., et al. [10] detected RCH in non-diapausing C. suppressalis mature larvae. It is not clear if $\mathrm{RCH}$ also occurs and contributes to low temperature survival in the diapausing/overwintering C. suppressalis larvae.

The present study aims to determine if $\mathrm{RCH}$ occurs in diapausing $C$. suppressalis larvae and contributes to survival of the larvae at sub-zero temperatures during overwintering and how long the effects of $\mathrm{RCH}$ on low temperature survival can last.

\section{Materials and Methods}

\subsection{Insects and Diapause Induction}

Newly hatched C. suppressalis larvae from a laboratory culture maintained for 5 years were reared in groups at 10 neonates per glass tube (diameter $2.5 \mathrm{~cm}$, length $10 \mathrm{~cm}$ ) on an artificial diet [20] in a climate chamber RXZ-260B (Jiangnan Instrument Plant, Ningbo, China) at $25 \pm 1{ }^{\circ} \mathrm{C}, 75 \pm 5 \%$ relative humidity and LD12:12. From the third stadium, the larvae were reared individually in glass tubes and the diet was replenished one time at $10 \mathrm{~d}$ after individual rearing was initiated. It is not possible to distinguish diapausing larvae from non-diapausing larvae from their appearance in this insect species. C. suppressalis larvae that did not pupate within $51 \mathrm{~d}$ under the mentioned conditions were considered to have entered diapause [16].

\subsection{Determination of Discriminating Temperature}

In the induction and detection of $\mathrm{RCH}$, a standard cold shock temperature (discriminating temperature) has to be established for comparison of survival at low temperatures. The discriminating temperature is defined as the low temperature that resulted in $80 \%$ mortality $[4,8]$. The diapausing larvae were exposed directly from the rearing temperature of $25{ }^{\circ} \mathrm{C}$ [4] to a series of sub-zero temperatures $\left(-11,-12,-13,-14\right.$, and $\left.-15^{\circ} \mathrm{C}\right)$ for an exposure period of $2 \mathrm{~h}$ using controlled climate chambers VM04/100 (Heraeus Votsch, Hanau, Germany). The sub-zero temperatures and the treatment duration were employed so that mortalities of the larvae would approximate $80 \%$ according to a pilot study. After the treatment, the larvae were re-warmed at $1{ }^{\circ} \mathrm{C} / \mathrm{min}$ to the rearing temperature $\left(25^{\circ} \mathrm{C}\right)$ and then the larvae were individually transferred to the artificial diet in glass tubes. Survival was assessed at $24 \mathrm{~h}$ after the sub-zero temperature treatment. The larvae were recorded as dead if they showed no movement when touched with a soft brush. In a random design, 10 groups of 15 diapausing larvae were tested for each of the sub-zero temperatures.

\subsection{Induction and Detection of RCH Response}

To detect if $\mathrm{RCH}$ occurs in diapausing $\mathrm{C}$. suppressalis larvae and the conditions for its occurrence, 15 randomly selected larvae were individually transferred from the rearing temperature $\left(25^{\circ} \mathrm{C}\right)$ to $5{ }^{\circ} \mathrm{C}$, which are employed in previous studies [9], in a glass tube and maintained there for 1, 2, 3, or $4 \mathrm{~h}$. Then, the larvae were immediately subjected to the established discriminating temperature of $-14{ }^{\circ} \mathrm{C}$ for $2 \mathrm{~h}$ in the temperature chamber. Thereafter, the larvae were re-warmed at $1{ }^{\circ} \mathrm{C} / \mathrm{min}$ to the rearing temperature. Survival was assessed as above. The observation was repeated 10 times for each of the $5{ }^{\circ} \mathrm{C}$ steps. 


\subsection{Extent of RCH Response}

To assess the range of temperatures where $\mathrm{RCH}$ increases survival of diapausing $\mathrm{C}$. suppressalis larvae, survival of larvae with and without $\mathrm{RCH}$ was compared at a series of sub-zero temperatures. Diapausing larvae that had been subjected to $\mathrm{RCH}$ (at $5^{\circ} \mathrm{C}$ for $4 \mathrm{~h}$ ) were transferred to temperatures at and around the discriminating temperature (i.e., $-12,-13,-14,-15$, and $-16^{\circ} \mathrm{C}$ ) and maintained there for $2 \mathrm{~h}$. Larvae directly transferred from the rearing temperature to the sub-zero temperatures were used as the control. Then, the temperatures were increased to the rearing temperature at $1{ }^{\circ} \mathrm{C} / \mathrm{min}$ and survival of the larvae was checked as above. For each of the sub-zero temperatures, 10 random replicates of 15 larvae were tested.

\subsection{Durability of RCH Response}

To determine the durability of $\mathrm{RCH}$ response, fifteen diapausing $\mathrm{C}$. suppressalis larvae that had undergone $\mathrm{RCH}$ conditions were re-warmed at $1{ }^{\circ} \mathrm{C} / \mathrm{min}$ to $25^{\circ} \mathrm{C}$ and maintained at the temperature for $0,0.5,1$, and $2 \mathrm{~h}$ prior to exposure to the discriminating temperature for $2 \mathrm{~h}$. Then, the larvae were re-warmed again at $1{ }^{\circ} \mathrm{C} / \mathrm{min}$ to $25^{\circ} \mathrm{C}$ and thereafter transferred individually to glass tubes with artificial diet and assessed for survival as above. The tests were replicated 10 times.

\subsection{Statistical Analysis}

Survival data were subjected to one-way analysis of variance (ANOVA), where applicable, for low temperature treatment effects and means were separated by Tukey HSD test. A two-way ANOVA was used to detect the extent of $\mathrm{RCH}$ response, where survival rate is the responding variable and $\mathrm{RCH}$ treatment and the sub-zero temperature are the two predicting variables. The data were arcsine-square root transformed and tested for homogeneity of variance before ANOVA. All the statistical analyses were performed using SPSS 13.0 for Windows (IBM, Armonk, NY, USA).

\section{Results}

\subsection{Discriminating Temperature}

To determine the discriminating temperature that results in $80 \%$ mortality, diapausing C. suppressalis larvae were directly exposed from $25^{\circ} \mathrm{C}$ to sub-zero temperatures for $2 \mathrm{~h}$. Their mean survival is shown in Figure 1. Survival of the larvae ranged from nearly zero to more than $90 \%$ and was significantly reduced $(F=361.55, \mathrm{df}=4,45, p<0.001)$ with each $1{ }^{\circ} \mathrm{C}$ reduction in temperature (Tukey HSD, $p<0.001$ ). Larvae exposed to $-11,-12,-13,-14$, and $-15{ }^{\circ} \mathrm{C}$ survived at $92 \%, 66 \%$, $47 \%, 21 \%$, and less than $1 \%$, respectively. Therefore, the discriminating temperature that resulted in approximately $80 \%$ mortality following $2 \mathrm{~h}$ exposure was determined to be $-14{ }^{\circ} \mathrm{C}$.

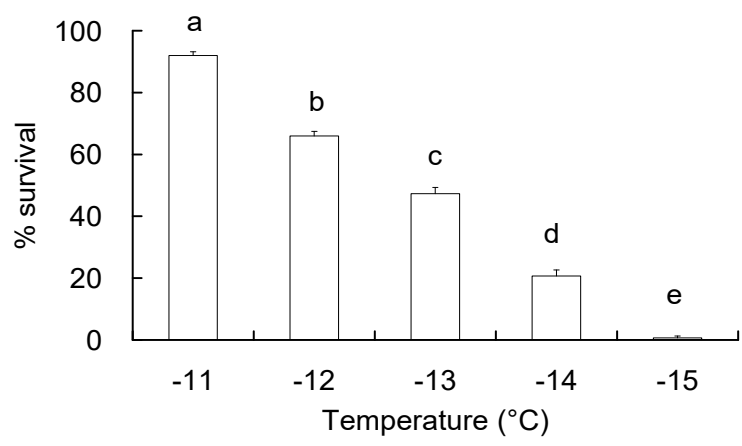

Figure 1. Survival (means $\pm \mathrm{SE}$ ) of diapausing C. suppressalis larvae for determination of discriminating temperature. The larvae were directly transferred to sub-zero temperatures from rearing temperature $\left(25^{\circ} \mathrm{C}\right)$ and maintained there for $2 \mathrm{~h}$ and then examined $24 \mathrm{~h}$ after the larvae were re-warmed to $25^{\circ} \mathrm{C}$. Different letters over the bars indicate significant differences (Tukey HSD test, $p<0.05$ ). 


\section{2. $R C H$ Response}

The diapausing C. suppressalis larvae were subjected to $5{ }^{\circ} \mathrm{C}$ for $0-4 \mathrm{~h}$ and then immediately to the discriminating temperature for $2 \mathrm{~h}$ to detect if $\mathrm{RCH}$ occurs in the diapausing larvae. After the treatment, the larvae survived at significantly different rates $(F=24.62, \mathrm{df}=4,49, p<0.001$; Figure 2). Survival of the rapidly cold-hardened (i.e., $1-4 \mathrm{~h}$ at $5{ }^{\circ} \mathrm{C}$ ) larvae was enhanced by $4.7-20.0 \%$. The $\mathrm{RCH}$ effect on survival became significant with 2 -h acclimation at $5{ }^{\circ} \mathrm{C}$ (an increase of $11 \%$ over no $\mathrm{RCH}$, i.e., $0 \mathrm{~h}$ at $5^{\circ} \mathrm{C}$ ) and reached even higher with acclimation for $4 \mathrm{~h}$ (an increase of 20 percentage points over no $\mathrm{RCH})$.

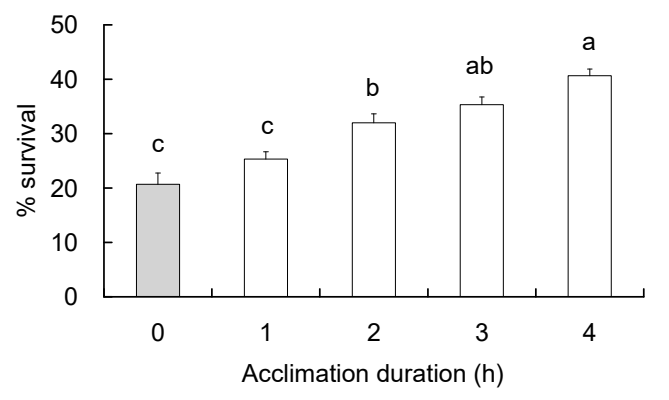

Figure 2. Survival (means $\pm \mathrm{SE}$ ) of diapausing $\mathrm{C}$. suppressalis larvae in detection of $\mathrm{RCH}$ response. The larvae were exposed to $5{ }^{\circ} \mathrm{C}$ for $0-4 \mathrm{~h}$ and then transferred to the discriminating temperature $\left(-14^{\circ} \mathrm{C}\right)$ and maintained there for $2 \mathrm{~h}$. Survival was examined $24 \mathrm{~h}$ after the larvae were re-warmed to $25^{\circ} \mathrm{C}$ from $-14^{\circ} \mathrm{C}$. Different letters over the bars indicate significant difference (Tukey HSD test, $p<0.05)$.

\subsection{Extent of RCH Response}

To examine the extent of $\mathrm{RCH}$ response, the diapausing $\mathrm{C}$. suppressalis larvae that had either experienced $\mathrm{RCH}$ at $5{ }^{\circ} \mathrm{C}$ for $4 \mathrm{~h}$ or not were subjected to sub-zero temperatures $(-12,-13,-14$, -15 , and $-16{ }^{\circ} \mathrm{C}$ ) in 10 groups of 15 larvae. The larvae that experienced no $\mathrm{RCH}$ did not survive at all at $-16^{\circ} \mathrm{C}$ and at $-15{ }^{\circ} \mathrm{C}$, only one out of 15 larvae survived in just two among the 10 groups (Figure 3). The RCH-experienced larvae survived only one out of 15 at $-16^{\circ} \mathrm{C}$ and at $-15{ }^{\circ} \mathrm{C}$ in just two and five among the ten groups, respectively. Due to the near zero survival at both -15 and $-16^{\circ} \mathrm{C}$, the survival data at these temperatures were not included in the final statistical analysis. At the other three temperatures, survival of the larvae was significantly influenced by the sub-zero temperature $(F=249.49, \mathrm{df}=3,60, p<0.001)$, the $\mathrm{RCH}(F=79.07, \mathrm{df}=2,60, p<0.001)$, and their interaction $(F=8.00$, $\mathrm{df}=2,60, p=0.001$; Figure 3). Survival rates were reduced with each $1^{\circ} \mathrm{C}$ reduction in temperature (Tukey HSD, $p<0.001$ ) and were higher in the cold-hardened larvae than in the larvae that experienced no RCH.

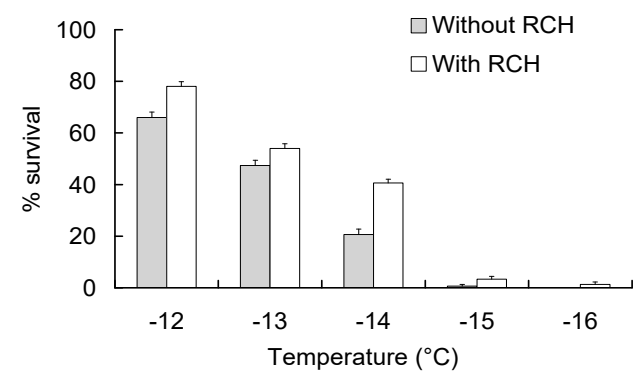

Figure 3. Survival (means $\pm \mathrm{SE}$ ) of diapausing $C$. suppressalis larvae at sub-zero temperatures for effects of $\mathrm{RCH}$. The larvae either rapidly cold hardened at $5{ }^{\circ} \mathrm{C}$ for $4 \mathrm{~h}$ or not cold-hardened were transferred to the sub-zero temperatures and maintained for $2 \mathrm{~h}$. Survival was examined $24 \mathrm{~h}$ after the larvae were re-warmed to $25^{\circ} \mathrm{C}$ from the sub-zero temperatures. 


\subsection{Durability of RCH Response}

Durability of $\mathrm{RCH}$ response was tested through maintaining the $\mathrm{RCH}$-experienced diapausing larvae (acclimated at $5{ }^{\circ} \mathrm{C}$ for $4 \mathrm{~h}$ ) for different durations at the rearing temperature $\left(25^{\circ} \mathrm{C}\right)$ before they were exposed to the discriminating temperature. With these treatments, their survival differed significantly $(F=37.97, \mathrm{df}=3,39, p<0.001$; Figure 4$)$. The survival rates were significantly decreased by $8 \%$ (Tukey HSD, $p=0.002$ ), $16 \%$ (Tukey HSD, $p<0.001$ ) and $18 \%$ (Tukey HSD, $p<0.001$ ) for the $0.5,1$, and $2 \mathrm{~h}$ maintenance durations, respectively, as compared to that without maintenance at $25^{\circ} \mathrm{C}$. Further, the larvae that experienced $\mathrm{RCH}$ and post- $\mathrm{RCH}$ maintenance were compared to the larvae directly transferred to the discriminating temperature (i.e., no $\mathrm{RCH}$ ). It was found that the larvae differed significantly in their survival rates $(F=28.63, \mathrm{df}=4,49, p<0.001)$. However, the larvae that experienced $\mathrm{RCH}$ and were maintained for 1 and $2 \mathrm{~h}$ post $\mathrm{RCH}$ showed similar survival rates with the larvae that did not experience RCH (Tukey HSD, $p>0.125$ ).

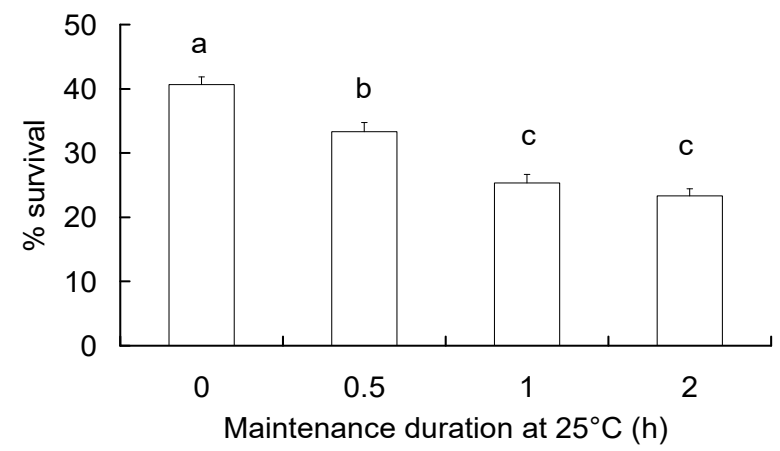

Figure 4. Survival (means $\pm \mathrm{SE}$ ) of diapausing $C$. suppressalis larvae in tests for durability of RCH effect. The $\mathrm{RCH}$-experienced larvae were transferred directly or after maintenance of $0.5,1$ or $2 \mathrm{~h}$ at $25^{\circ} \mathrm{C}$, to the discriminating temperature $\left(-14^{\circ} \mathrm{C}\right)$ and maintained there for $2 \mathrm{~h}$. Survival was examined $24 \mathrm{~h}$ after the larvae were re-warmed to $25{ }^{\circ} \mathrm{C}$ from $-14{ }^{\circ} \mathrm{C}$. Different letters over the bars indicate significant difference (Tukey HSD test, $p<0.05$ ).

\section{Discussion}

Different temperature acclimation regimes can induce $\mathrm{RCH}$ in terrestrial arthropods. In the present study, $\mathrm{RCH}$ was induced in diapausing C. suppressalis larvae after a short exposure $(2-4 \mathrm{~h})$ at $5{ }^{\circ} \mathrm{C}$. In many other insects, $\mathrm{RCH}$ has been induced at temperatures ranging $0-5{ }^{\circ} \mathrm{C}[7,8,21-25]$, or even at $10^{\circ} \mathrm{C}$ for the predatory mite Euseius (Amblyseius) finlandicus [21] and the fruit fly Bactrocera oleae [22] and $-2{ }^{\circ} \mathrm{C}$ for a Karoo beetle Afrinus sp [26]. In non-diapausing C. suppressalis mature larvae, a previous report showed that $\mathrm{RCH}$ could be induced at $0{ }^{\circ} \mathrm{C}$ for $4 \mathrm{~h}$ and to a lesser extent, at $5{ }^{\circ} \mathrm{C}$ for $4 \mathrm{~h} \mathrm{[10].} \mathrm{Apart} \mathrm{from} \mathrm{the} \mathrm{abrupt} \mathrm{cooling} \mathrm{(insects} \mathrm{are} \mathrm{transferred} \mathrm{directly} \mathrm{from} \mathrm{rearing} \mathrm{temperature}$ to a lower acclimation temperature), gradual cooling at rates of $0.5{ }^{\circ} \mathrm{C}$ per minute or lower has been documented to induce RCH in several insect species $[3,8,13,21,22,27]$. Whether $\mathrm{RCH}$ can be induced in diapausing C. suppressalis larvae after a short exposure to gradual cooling has to be further examined.

In several insect species, induction of $\mathrm{RCH}$ could be accomplished in as short as $0.5 \mathrm{~h}$ at temperatures between 0 and $5{ }^{\circ} \mathrm{C}$ [7]. In the present study, $2 \mathrm{~h}$ exposure to $5{ }^{\circ} \mathrm{C}$ resulted in a significant increase (by $11 \%$ ) of survival in diapausing C. suppressalis larvae exposed to the discriminating temperature and an increase of $20 \%$ was recorded with a $4 \mathrm{~h}$ exposure. This contrasts to the non-diapausing C. suppressalis mature larvae [10], where a $2 \mathrm{~h}$ exposure to $5^{\circ} \mathrm{C}$ was not able to induce $\mathrm{RCH}$. Similarly, the acclimation durations for a considerable increase in the effects of cold hardening are 1-2 $\mathrm{h}$ in Euseius finlandicus [21] and Bactrocera oleae [22], which are also freeze tolerant species.

The protection from cold shock gained through $\mathrm{RCH}$ for the diapausing $\mathrm{C}$. suppressalis larvae was lost within $1 \mathrm{~h}$ of their return to $25^{\circ} \mathrm{C}$, decreasing by 18 percentage points. In the rapid-cold hardened non-diapausing $\mathrm{C}$. suppressalis mature larvae, survival gained through $\mathrm{RCH}$ decreased from more than 
$45 \%$ to around $20 \%$ when the $\mathrm{RCH}$-experienced larvae were maintained for $1 \mathrm{~h}$ at room temperature before their exposure to the discriminating temperature [10]. The same situation occurred in Musca domestica [3], F. occidentalis [8], Psacothea hilaris [9], and Corythucha ciliate [23], while in E. finlandicus [21], it lasted for $2 \mathrm{~h}$ and for $0.25 \mathrm{~h}$ in B. oleae [22]. These results indicate that the cold tolerance gained through RCH is plastic [21]. However, in contrast to the results of Qiang et al. [10], our results show that the protection gained through $\mathrm{RCH}$ was lost at a lower rate in the diapausing $\mathrm{C}$. suppressalis larvae compared to non-diapausing larvae. Moreover, in the natural environment, the diapausing larvae may experience abrupt drops of temperature in the autumn and early spring. However, an immediate rapid increase in temperature is rare, as that administered in the tests for the durability of $\mathrm{RCH}$ response. It can be reasoned that the protection gained through $\mathrm{RCH}$ may not be lost so quickly in the natural environment as in this study. Therefore, $\mathrm{RCH}$ may play a role in preparing the diapausing overwintering C. suppressalis larvae for abrupt temperature drops in the field that would otherwise be lethal.

The mechanisms underlying $\mathrm{RCH}$ responses have not been extensively explored. In a recent review, Teets, N.M. and Denlinger, D.L. [12] summarized that canonical cold-hardening mechanisms are either not associated with $\mathrm{RCH}$ or evidence for their involvement in $\mathrm{RCH}$ is inconclusive. The RCH-related physiological adjustments are often small [12]. RCH only elicited few changes in the abundance of detectable proteins in D. melanogaster [13]; and in Locusta migratoria, heat shock proteins were generally down-regulated [24]. According to Teets, N.M. and Denlinger, D.L. [12], cryoprotectant synthesis, membrane restructuring, adjustments to ion transport mechanisms, and cell-mediated signalling pathways are potential mechanisms associated with $\mathrm{RCH}$. In contrast, the up-regulation of stress-related genes and synthesis of anti-freeze proteins and/or ice nucleating agents are not likely connected with $\mathrm{RCH}$. Further studies of the mechanisms underlying $\mathrm{RCH}$ and the relation between $\mathrm{RCH}$ effects and SCP change in this species will be performed.

\section{Conclusions}

Our results indicate that $\mathrm{RCH}$ can be induced in diapausing $\mathrm{C}$. suppressalis larvae through a short time exposure $\left(2-4 \mathrm{~h}\right.$ ) to a low temperature of $5{ }^{\circ} \mathrm{C}$, and this confers increased survival at sub-zero temperatures. Although $\mathrm{RCH}$ effects on sub-zero temperature survival is lost within $1 \mathrm{~h}$ on return of the $\mathrm{RCH}$-experienced diapausing larvae to the room temperature, the protection gained through $\mathrm{RCH}$ is relatively strong in the diapausing larvae compared with non-diapausing larvae of $C$. suppressalis. Thus, it is reasonable to assume that $\mathrm{RCH}$ that may occur in diapausing $\mathrm{C}$. suppressalis larvae during the late autumn and early winter may contribute to its overwintering success.

Author Contributions: M.H. and G.Y. designed the study. G.Y. and Y.H. conducted the experiments. G.Y., J.W. and M.H. analyzed the data. All authors joined in the manuscript writing.

Acknowledgments: We thank Mei Huang for technical assistance. This research was supported by a grant from National Natural Science Foundation of PR China (31071681).

Conflicts of Interest: The authors declare no conflicts of interest.

\section{References}

1. Overgaard, J.; MacMillan, H.A. The integrative physiology of insect chill tolerance. Annu. Rev. Physiol. 2017, 79, 187-208. [CrossRef] [PubMed]

2. Lee, R.E., Jr.; Denlinger, D.L. Rapid cold-hardening: Ecological significance and underpinning mechanisms. In Low Temperature Biology of Insects; Denlinger, D.L., Lee, R.E., Jr., Eds.; Cambridge University Press: Cambridge, UK, 2010; pp. 35-58, ISBN 9780521886352.

3. Coulson, S.J.; Bale, J.S. Characterisation and limitations of the rapid cold-hardening response in the housefly Musca domestica (Diptera: Muscidae). J. Insect Physiol. 1990, 36, 207-211. [CrossRef] 
4. Powell, S.J.; Bale, J.S. Cold shock injury and ecological costs of rapid cold hardening in the grain aphid Sitobion avenae (Hemiptera: Aphididae). J. Insect Physiol. 2004, 50, 277-284. [CrossRef] [PubMed]

5. Lee, R.E., Jr.; Chen, C.P.; Denlinger, D.L. A rapid cold-hardening process in insects. Science 1987, 238, 1415-1417. [CrossRef] [PubMed]

6. MacMillan, H.A.; Guglielmo, C.G.; Sinclair, B.J. Membrane remodeling and glucose in Drosophila melanogaster: A test of rapid cold-hardening and chilling tolerance hypotheses. J. Insect Physiol. 2009, 55, 243-249. [CrossRef] [PubMed]

7. Czajka, M.C.; Lee, R.E., Jr. A rapid cold-hardening response protecting against cold shock injury in Drosophila melanogaster. J. Exp. Biol. 1990, 148, 245-254. [PubMed]

8. McDonald, J.R.; Bale, J.S.; Walters, K.F.A. Rapid cold hardening in the western flower thrips Frankliniella occidentalis. J. Insect Physiol. 1997, 43, 759-766. [CrossRef]

9. Shintani, Y.; Ishikawa, Y. Relationship between rapid cold-hardening and cold acclimation in the eggs of the yellow-spotted longicorn beetle, Psacothea hilaris. J. Insect Physiol. 2007, 53, 1055-1062. [CrossRef] [PubMed]

10. Qiang, C.-K.; Du, Y.-Z.; Yu, L.-Y.; Cui, Y.-D.; Zheng, F.-S.; Lu, M.-X. Effect of rapid cold hardening on the cold tolerance of the larvae of the rice stem borer, Chilo suppressalis (Walker). Agric. Sci. China 2008, 7, 321-328. [CrossRef]

11. Overgaard, J.; Malmendal, A.; Sorensen, J.G.; Bundy, J.G.; Loeschcke, V.; Nielsen, N.C.; Holmstrup, M. Metabolomic profiling of rapid cold hardening and cold shock in Drosophila melanogaster. J. Insect Physiol. 2008, 53, 1218-1232. [CrossRef] [PubMed]

12. Teets, N.M.; Denlinger, D.L. Physiological mechanisms of seasonal and rapid cold-hardening in insects. Physiol. Entomol. 2013, 38, 105-116. [CrossRef]

13. Overgaard, J.; Sorensen, J.G.; Comc, E.; Colinet, H. The rapid cold hardening response of Drosophila melanogaster: Complex regulation across different levels of biological organization. J. Insect Physiol. 2014, 62, 46-53. [CrossRef] [PubMed]

14. Park, Y.; Kim, K.; Kim, Y. Rapid cold hardening of Thrips palmi (Thysanoptera: Thripidae). Environ. Entomol. 2014, 43, 1076-1083. [CrossRef] [PubMed]

15. Hou, M.; Lin, W.; Han, Y. Seasonal changes in supercooling points and glycerol content in overwintering larvae of the Asiatic rice borer from rice and water-oat plants. Environ. Entomol. 2009, 38, 1182-1188. [CrossRef] [PubMed]

16. Chen, F.; Han, Y.; Hu, Q.; Hou, M. Diapause induction and photoperiodic clock in Chilo suppressalis Walker (Lepidoptera: Crambidae). Entomol. Sci. 2011, 14, 283-290. [CrossRef]

17. Su, J.-W.; Xuan, W.-J.; Sheng, C.-F.; Ge, F. Biology of overwintering larvae of the Asiatic rice borer, Chilo suppressalis, in paddy fields of Northeast China. Entomol. Knowl. 2003, 40, 323-325.

18. Izumi, Y.; Sonoda, S.; Tsumuki, H. Effects of diapause and cold-acclimation on the avoidance of freezing injury in fat body tissue of the rice stem borer, Chilo suppressalis Walker. J. Insect Physiol. 2007, 53, 685-690. [CrossRef] [PubMed]

19. Hou, M.; Han, Y.; Lin, W. Influence of soil moisture on supercooling capacity and associated physiological parameters of overwintering larvae of the rice stem borer. Entomol. Sci. 2009, 12, 155-161. [CrossRef]

20. Han, L.; Li, S.; Liu, P.; Peng, Y.; Hou, M. New artificial diet for continuous rearing of Chilo suppressalis (Lepidoptera: Crambidae). Ann. Entomol. Soc. Am. 2012, 105, 253-258. [CrossRef]

21. Broufas, G.D.; Koveos, D.S. Rapid cold hardening in the predatory mite Euseius (Amblyseius) finlandicus (Acari: Phytoseiidae). J. Insect Physiol. 2001, 47, 699-708. [CrossRef]

22. Koveos, D.S. Rapid cold hardening in the olive fruit fly Bactrocera oleae under laboratory and field conditions. Ent. Exp. Appl. 2001, 101, 257-263. [CrossRef]

23. Ju, R.-T.; Xiao, Y.-Y.; Li, B. Rapid cold hardening increases cold and chilling tolerances more than acclimation in the adults of the sycamore lace bug, Corythucha ciliata (Say) (Hemiptera: Tingidae). J. Insect Physiol. 2011, 57, 1577-1582. [CrossRef] [PubMed]

24. Cui, F.; Wang, H.; Zhang, H.; Kang, L. Anoxic stress and rapid cold hardening enhance cold tolerance of the migratory locust. Cryobiology 2014, 69, 243-248. [CrossRef] [PubMed]

25. Cha, W.H.; Lee, D. Identification of rapid cold hardening-related genes in the tobacco budworm, Helicoverpa assulta. J. Asia-Pac. Entomol. 2016, 19, 1061-1066. [CrossRef] 
26. Sinclair, B.J.; Chown, S.L. Rapid cold-hardening in a Karoo beetle, Afrinus sp. Physiol. Entomol. 2006, 31, 98-101. [CrossRef]

27. Wang, X.H.; Kang, L. Rapid cold-hardening in young hoppers of the migratory locust Locusta migratoria L. (Orthoptera: Acridiidae). CryoLetters 2003, 24, 331-340. [PubMed] 